\title{
S.2. A Case against the Categorisation of Children and Youth
}

\section{Part 1: Theoretical perspectives}

\author{
Peter Stanley
}

Senior Lecturer, Waikato University, Tauranga

\section{ABSTRACT}

This is the first of two articles that provide a critique of categorisation and of the biomedical interpretation of personal adjustment issues experienced by children and youth. In this paper the appraisal is made by the devising of an imaginary mental illness, through the presentation of some important theoretical frameworks, by considering contributions from contemporary developmental psychology, and through a brief linguistic, historical and policy analysis. These viewpoints are severely critical, both individually and collectively, of categorisation and the medical model. The critique is further strengthened by a professional practice perspective that will be published in Kairaranga in September.

\section{Position paper}

KEYWORDS

Clinical diagnosis, adjustment disorders, diagnostic and statistical manual, psychological assessment, mental disorders.

\section{INVENTING ACADEMIC DEFICIENCY DISORDER}

It is remarkably easy to invent a mental illness or special education category. You start with an idealised state of personal well-being and then you catalogue the various ways that real people deviate from this fictional standard. My invention of academic deficiency disorder (see Table 1) is referenced to the perfect university student: a paragon of tireless efficiency without a shred of self-doubt. Once a list of personal attributes and dimensions is assembled it should be given a medical-sounding name (and acronym), and preferably one that includes a value-laden term such as disorder, disturbance, dysfunction or deficit. The job is then just about done, and academic deficiency disorder might find a place in the Diagnostic and Statistical Manual of Mental Disorders (DSM-IV) (American Psychiatric Association, 2000), which is the standard catalogue of mental illnesses and conditions, and which has been described as 'the most powerful book in psychiatry and clinical psychology' (Maddux, 2002, p. 15).
TABLE 1

Diagnosis of Academic Deficiency Disorder

\section{ACADEMIC DEFICIENCY DISORDER}

\section{Criteria Description}

A At least six of the following symptoms of deficiency have persisted for at least six months to a degree that is maladaptive and inconsistent with developmental level.

1. Often rushes work as assignment deadlines approach.

2. Often thinks that other people in tutorial groups have more intelligent things to say.

3. Often feels tired when confronted with major academic tasks.

4. Often finds other activities more attractive than academic work.

5. Often anxious that they will be "found out" as not capable of university study.

6. Often experiences some disappointment with how assignments turn out or are graded.

7. Often feels a little depressed and anxious as a student.

8. Often worries about the costs associated with academic study.

9. Often concerned about the future and whether the study will lead to employment.

B Onset no earlier than 18 years of age.

C Symptoms must be present in two or more situations (for example, at university, work and at home).

D The disturbance causes clinically significant distress or impairment in social, academic, or occupational functioning.

The ease with which categories can be created is only rivalled by the enthusiasm with which people ascribe complaints and diagnoses to themselves and others. When I was in practice as a psychologist, a book was published on hyperactivity in children and I remember a number of parents declaring that the author was talking to them directly and personally, "He's summed up Jason to a 'T'." In effect, the text provided a definition of childhood and the application of a label did little more, or less, than individualise, and pathologise, a universal experience. It seems that many people have a negative confirmatory bias, where they search their present circumstances and pasts for evidence to support a diagnosis, or other pejorative judgment, while simultaneously discounting signs of competence and success (Seligman, 2002). 
Categorisation is a human thing to do, and even among those who rally against it there will be those who use the terms 'at-risk' and 'resilient', and who refer to a child on the Ongoing Reviewable Resourcing Scheme as an 'ORRS' child. Very few of the psychiatric and special education labels that are applied to children and youth are statements of fact in the sense that conclusive biological dysfunctions have been identified for them (Albee, 1999; Jensen \& Hoagwood, 1997; Thakker \& Ward, 1998). There are important exceptions, such as the intellectual difficulties associated with phenylketonuria (PKU) that have clear genetic causation (Santrock, 2006). Obviously, both physical constitution and dispositional factors and environmental events contribute to behaviour. What is being objected to here are attempts to portray common children's issues as largely or exclusively caused by physical factors. A further instance of this sort of practice is when some changes in brain structure are cited as the origin of personal problems, such as the larger ventricles in the brains of people with schizophrenia (American Psychiatric Association, 2000). However, a variety of experiences can impact on brain structure (including becoming a London taxi driver, apparently) and, according to Bentall (2004a), whether the changes are seen as pathological is a matter of selective judgment.

Francis, First and Pincus (2000), who are among the principal proponents of DSM-IV, acknowledge that this diagnostic system is inherently limited because it simply provides lists of signs and symptoms and, to use their own words, 'It is not based on a deep understanding of mental disorders because in most cases we lack that understanding' (p. 6). Francis et al. (2000) also assert that in the future the exact nature and causes of psychiatric disorders will be revealed 'through the powerful tools of neuroscience and clinical research' (p. 7). Sameroff (2000) responds to this conclusion by saying that it can be interpreted in two ways: first as a statement of fact and second as an expression of a biological belief system. Interestingly, recent advances in basic research are showing that some specific biological problems could be reflected in a number of psychosocial difficulties (Singh, 2001). In other words, the technological findings appear to be contradicting, rather than supporting, current categorisations.

\section{SOME THEORETICAL FRAMEWORKS}

The foregoing analysis leads to a central criticism of DSM-IV; that it is actually a misappropriation of a physical medical model to psychological problems. This theme is strongly echoed in the critiques of the DSM-IV as pseudoscience (Doucette, 2002; Houts, 2002), by postmodern perspectives on the nature of reality and knowledge (Danforth, 2002; Maddux, 2002), and through political commentary (Szasz, 1974; Schaler, 2004). The charge that DSM-IV is essentially unscientific has two related components. Firstly, this system of classification is atheoretical, or in layperson terms, it is unclear what it's on about but it provides a presumption that personal problems are illnesses and people with these problems are sick. True science is concerned with, and about, theory development. The second point is that an integrated theoretical position (as we have with evolutionary theory) minimises the number of categories in a taxonomic system rather than continually expanding them. Over the past 40 years there has been a 300 percent increase in the number of the diagnoses available across DSMs I to IV (Houts, 2002). Little wonder then that authorities like Bentall (2004b) have concluded that psychiatric categories are no more scientific than the pastime of astrology.

We regularly encounter poor scientific thinking in the community. Common examples include the confusion of foods with drugs ("Sugar is rocket fuel for my son") and the attribution of special properties to pharmaceuticals ("Ritalin taught Toby to read"). More significant perhaps are the mistaken perceptions of the power of genetics. Genes are seen as far more than scripts for proteins (Santrock, 2006). Everyday parlance can suggest that they contain finished behavioural performances that are just waiting to be displayed and confirm our deepest suspicions, hopes and fears. This view of the gene has substantial historical precedent in preformationism, a thesis that flourished in the seventeenth and eighteenth centuries, and which proposed that perfectly-formed human shapes existed in sperm or in the ovaries (Pinto-Correia, 1997). The observation that needs to be made here is that while misunderstandings about drugs and genes may flourish in the community, it can come as some surprise to find unscientific thinking in the work systems of many psychologists and psychiatrists.

Postmodernism offers a more strident critique of DSM-IV and the medical approach since it questions the very validity of having scientific aspirations and the search for objective truth (Danforth, 2002; Maddux, 2002). The idea that there are real mental illnesses, and that they are part of the nature of things, is depicted as a discovery narrative. Such an account might be set alongside a social invention narrative, where truth is seen in terms of what people find useful (Houts, 2002). A classic example of the social invention narrative in operation was the decision in 1973 by the American Psychiatric Association to delete homosexuality as a disorder. Same-sex attraction ceased to be an illness because psychiatrists voted for its removal (Bayer, 1981); although, as it happens, everything in the DSMs is there by consensus. Houts (2002) contends that there are at least three parties to any diagnosis - the patient, society and professionals - and all of them can perceive benefits in it. The patient can obtain an explanation for their troubling behaviour, they may receive services and they are entitled to the sick role. Society and others such as relatives, and pharmaceutical manufacturers, gain when a "disturbed" person is either changed or removed, and for the practitioners there is order in what they do, as well as the more obvious prestige and monetary consequences.

Any analysis of the benefits or functions of diagnosis, as is promoted by a social invention analysis, also allows for the systematic study of costs or detractions, and the personal disadvantages that can be associated with labelling are legion (Ashman \& Elkins, 2002; Goffman, 1963). For parents there can be significant, if temporary, relief by obtaining a diagnosis for their child but the long-term implications for the young person themselves may include social marginalisation and rejection, and diminished self-esteem and self-efficacy. In a discussion of the concept of recovery from psychiatric disability, Carpenter (2002) comments 
that the process is as much about coping with the negative reactions of others as it is about dealing with the disability itself. Carpenter also contends that the medical model contains a presumption of chronicity, or long-term engagement with psychiatric ailments, despite the contrary evidence of numerous longitudinal studies.

Szasz's (Szasz, 1974; Schaler, 2004) political critique of the application of a medical model to what he describes as problems of living is based on a deceptively simple semantic distinction. Mental illness is a myth because a mind cannot be sick. Any complaint that is ascribed to the mind is by way of a metaphor and so the search for mental illnesses is illogical, as is the pursuit of mental health as a goal. According to this view, psychiatric categorisation is a highly suspect practice and it is here that Szasz makes a second important distinction. Diagnosis is not so much concerned with the description of disability as it is about the prescription of how people should live. The meaning is in the intent and the medically-masked process of categorisation conveys a defective personal identity, which then allows for other paternalistic, coercive and abusive responses. Like the introductory chapters of DSM-IV, which they oversaw, Francis, First and Pincus (2000) possess an especially disarming and inclusive writing style and they state that the $5 \mathrm{~cm}$ thick Manual should not be taken as literally as some fundamentalists take the Bible' (p. 6). Szasz also sees relevance in religious parallels and he says that it is a social fact that the idea of mental illness as a real illness is even more firmly rooted in the modern American mind than is the idea of God'(Schaler, 2004, p. 385). Arguably, the situation in this country is little different.

\section{THE RESILIENCE PERSPECTIVE ON DEVELOPMENT}

Over the last thirty years there has been a transformation in how child and adolescent problems are conceptualised (Masten \& Powell, 2003) and this has contributed enormously to our appreciation of why some young people develop problems and others do not. Doll and Lyon (1998) provide a summary of some of the relevant concepts from research and theorising about resilience, which also apply in other disciplines such as developmental psychopathology (Cicchetti $\&$ Cohen, 1995), and these are context, time, interaction, mechanisms and politics. The child is seen as inseparable from the situations, such as family and school, in which they live. It is understood that people travel along pathways over time and an assortment of risk and protective factors can affect their competence and ability to cope. As well, these risk and protective factors are thought of as dynamic forces that interact with each other. Another point, concerning mechanisms, is that there are processes in operation that move the young person more towards either positive or negative adjustment or outcomes. Lastly, the authors assert that an understanding of problem behaviour provides guidance for actions and interventions and demonstrating this is a political act.
I would like to elaborate a little more on two important notions from the new conceptualisation. The first of these concerns dose effects, or asset/liability gradients, which in the positive sense simply means that the more good things there are in children's lives the more likely they will be able to respond to age-related tasks and demands. The child's physical health and well-being is clearly a critical component here and it operates in an interactive way with the other dimensions and contexts of functioning. Recent research commentaries (such as, Luthar \& Zelazo, 2003) are strongly affirming that a caring parent figure is foremost amongst beneficial environmental influences. According to Masten (2001), competent care giving is 'ordinary magic' because it is a common human system that is also very special. Risk factors hurt children by damaging basic adaptational processes especially care giving, and for this reason alone it is more accurate to talk of emotional "injuries" rather than mental illnesses.

A second seminal concept concerns the nature of child and environment relations. According to the new view, children and the significant adults in their lives modify each other's behaviour to better and ill effects through innumerable daily exchanges (Sameroff, 1995). The Oregon Social Learning Centre Model of parent/child interactions (Reid, Patterson, \& Synder, 2002; www.oslc.org), exemplifies such a pattern of microsocial processes and events. This transactional interpretation contrasts with approaches that either solely or largely attribute behaviour to factors in the child or to qualities in the young person's social settings (Stanley, 2003). It is much less deterministic as it entails an understanding of children as an active organisers of experience, participating in their own development (Campbell, 1990).

It is likely that how we now think about children, development and context has left the medical model behind. Risk approaches, and DSM-IV is an elaborate compilation of risk factors, appear simplistic and onedimensional. However, it is a fact that unfettered risk approaches are also much more straight-forward and they are much easier to understand. Contemporary perspectives on development, by comparison, are highly complex and they offer no certainties. In the place of clear and confirmatory diagnoses we are offered hypotheses about "probabilistic interchanges" and the suggestion that very challenging behaviour is a variant of regular responding. The choice is between easy answers, where one thing (biology) is seen as invariably causing another (behaviour), and explanations that correspond much more closely to the diversity and dynamism of daily experience. It is not always appreciated that this is a real choice, as these represent different levels of understanding, and that it is not intellectually tenable to have what some may see as a balanced viewpoint and to accommodate both the medical model and contemporary developmental considerations. 


\section{LANGUAGE, HISTORY AND POLICY}

I have some interest in psychology and counselling as language forms and the vernacular of special education is a study in its own right. Some of the features of the genre are a multiplicity of terms, a love of acronyms and an incessant contemporary striving for innocuous names. Normalisation produced pressure for the use of politically correct language when referring to minority or marginalised groups (Krause, Bochner \& Duchesne, 2003). It resulted in person-first language and such labels as mentally challenged, physically challenged, and differently abled (Beard \& Cerf, 1994), and sometimes it may mean victimisation for those whose language is 'a month or so out of date' (Hall, 1997, p. xi). It is possible that the quest for nonstigmatising terms is a hopeless one and that every new generation of labels becomes pejorative with the passage of time. Today we shudder at "idiot" and cringe at "mentally defective", and already we are uncomfortable with "slow learner" and unsure about "ORRS". This mission has a second irony; some of the traditional terms such as crippled and handicapped are better at attracting charitable contributions (Neilson, 2005). Proponents of categorisation can contend that the practice aids communication and facilitates understanding (American Psychiatric Association, 2000) but a contrasting argument is provided by Zigler and Hodapp (1986). They comment that the innumerable categorisations that presently exist are 'a veritable Tower of Babel' (p. 54), that gets in the way when professionals talk to potential funders and the public. These authors also cite Maslow (1948), who said that when people have a name for something they think they comprehend it and they do not continue to give it due attention.

In education, as in life, there is a simple equation: categorisation equals separation (Ashman \& Elkins, 2002), and this has been repeatedly shown in history. Taylor (2002) cites this country's first piece of exclusionary legislation, the 1873 Act to Prevent the Introduction of Imbecile Persons into the Colony of New Zealand. Specifically, the Act sought to prohibit the immigration of people "being either lunatic, idiotic, deaf, dumb, blind, or infirm' (p. 29), who might draw on public funds in the five years after arriving. In many countries in the early decades of the last century, genetic explanations of individual differences had a special prominence. Connections were seen between intellectual disability and mental illness, poverty, and criminality, and a perception of the feeble-minded as a parasitic and predatory class was not unusual (Zigler \& Hodapp, 1986). The eugenics movement and the rise of the residential institution were closely related to biological views of behaviour and present day advocates of categorisation and segregated placements should probably be mindful of this history and of the other extensions of locating cause in the person such as highly dubious chemical and physical "treatments" (Breggin, 1991), and even euthanasia for people with disabilities (Read \& Masson, 2004). Of course, how society treats people who are different inevitably reflects an assortment of changeable social, political and economic motives, as well as current best practices, and others may need to take cognisance that this also applies to normalisation and inclusion.

The wielding of authority over vulnerable people, including children and youth, is challenged by a raft of interrelated philosophical, professional and policy initiatives in New Zealand. These include developments in the diversity movement, the rise of strengths-based practices in the social services, the acceptance of new conceptions of client and practitioner relations, and the publication of government policy guidelines that embrace all of the foregoing emphases. Cultural groups and people with disabilities are alike in their resistance to dominating discourses, demands for emancipation and autonomy, and explicit rejection of deficit models (Bishop \& Glynn, 1999; O’Brien \& Ryba, 2005; Sullivan, 1991). Strengths-based approaches celebrate what clients can do, rather than being preoccupied with personal liabilities, and dismiss labels associated with pathology (Glicken, 2004; www.jamesfamily.org.nz). Client and practitioner relations characterised by consultation and collaboration, and family-based work in particular, are receiving increasing emphasis, and in this context categorisation is also seen as an impediment (Fraser, 2005; Stanley \& Stanley, 2005; Turnbull, Turbiville, \& Turnbull, 2000). New Zealand's Agenda for Children: Making life better for children (Ministry of Social Development, 2002) is for all parties who develop policies and provide services for children and it promotes an inclusive, whole-child approach and evidence-based, preventive programmes. Similarly, Youth Development Strategy Aotearoa: Action for child and youth development (Ministry of Youth Affairs, 2002), which applies to those aged from 12 to 24 years, advocates an ecological, risk and protective factors approach that acknowledges diversity and avoids 'defining the young person as "the problem"' (p. 20).

\section{CONCLUSION}

In conclusion we might consider another, and a more personal, perspective that is provided by Van der Klift and Kunc (1994), and that has relevance to the complex question of categorisation. These authors describe the "helperhelpee" relationship as inherently unequal and loaded with demeaning messages. When we offer help, our capacity, worth and superiority is affirmed. By contrast, when we are the recipients of assistance we inevitably feel deficient, inferior, a burden and obligated. The problem with categorisation is that it cements in place these unproductive properties that can pertain to professional relationships. Rather than responding to our young clients in authentic and respectful ways, 'our perceptions are based on stereotypical myths' that obscure 'the complexity and individuality we take for granted in ourselves' (Van der Klift \& Kunc, 1994, p. 399). 


\section{REFERENCES}

Albee, G. W. (1999). Prevention, not treatment, is the only hope. Counselling Psychology Quarterly, 12, 133-146.

American Psychiatric Association (2000). Diagnostic and statistical manual of mental disorders (4th ed., text revision). Washington, DC: Author.

Ashman, A., \& Elkins, J. (2002). Rights and learning opportunities. In A. Ashman \& J. Elkins (Eds.), Educating children with diverse abilities (pp.41-72). Frenchs Forest, NSW: Prentice.

Bayer, R. (1981). Homosexuality and American psychiatry: The politics of diagnosis. New York: Basic Books.

Beard, H., \& Cerf, C. (1994). The official politically correct dictionary and handbook. London, UK: HarperCollins.

Bentall, R. (2004a). Sideshow? Schizophrenia as construed by Szasz and the neo-Kraepelinians. In J. A. Schaler (Ed.), Szasz under fire: The psychiatric abolitionist faces his critics (pp. 301-320). Chicago: Open Court.

Bentall, R. P. (2004b). Abandoning the concept of schizophrenia. The cognitive psychology of hallucinations and delusions. In J. Read, L. R. Mosher, \& R. P. Bentall (Eds.), Models of madness: Psychological, social and biological approaches to schizophrenia (pp. 195-208). East Sussex, UK: Bruner.

Bishop, R., \& Glynn, T. (1999). Culture counts: Changing power relations in education. Palmerston North: Dunmore.

Breggin, P. R. (1991). Toxic psychiatry. New York: St Martin's.

Campbell, S. B. (1990). Behavior problems in preschool children: Clinical and developmental issues. New York: Guilford.

Carpenter, J. (2002). Mental health recovery paradigm: Implications for social work. Health \& Social Work 27(2). Retrieved May 18, 2005, from weblinks1.epnet.com. ezproxy. waikato.ac.nz:2048/citation.asp?tb=1\&_ua=bo + B...

Cicchetti, D., \& Cohen, D. J. (1995). Perspectives on developmental psychopathology. In D. Cicchetti \& D. J. Cohen (Eds.), Developmental psychopathology, Volume 1: Theory and methods (pp. 3-20). New York: Wiley.

Danforth, S. (2002). On what basis hope? Modern progress and postmodern possibilities. In M. Byrnes (Ed.), Taking sides. Clashing views on controversial issues in special education (pp.4-13). Guilford, CT: McGraw. (Reprinted from Mental Retardation, April, 1997).

Doll, B., \& Lyon, M. A. (1998). Introduction to the mini-series: Resilience applied: The promise and pitfalls of school-based resilience programs. School Psychology Review, 27, 346-347.

Doucette, A. (2002). Child and adolescent diagnosis: The need for a model-based approach. In L. E. Beutler \& M. L. Malik (Eds.), Rethinking the DSM: A psychological perspective (pp. 201-220). Washington, DC: APA Books.
Francis, A., First, M. B., \& Pincus, H. A. (2000). DSM-IV: Its value and limitations. In R. P. Halgin (Ed.), Taking sides: Clashing views on controversial issues in abnormal psychology (pp. 4-7). Guilford, CT: Dushkin/McGraw-Hill. (Reprinted from the Harvard Mental Health Letter, 11(12), June 1995).

Fraser, D. (2005). Collaborating with parents/caregivers and whānau. In D. Fraser, R. Moltzen, \& K. Ryba (Eds.), Learners with special needs in Aotearoa New Zealand (3rd ed., pp. 128-154). Southbank, Victoria: Thomson.

Glicken, M. D. (2004). Using the strengths perspective in social work practice: A positive approach for the helping professions. Boston: Pearson.

Goffman, E. (1963). Stigma: Notes on the management of spoiled identity. Englewood Cliffs, NJ: Prentice-Hall.

Hall, J. T. (1997). Social devaluation and special education: The right to full inclusion and an honest statement. London: Jessica Kingsley.

Houts, A. C. (2002). Discovery, invention, and the expansion of the modern diagnostic and statistical manuals of mental disorders. In L. E. Beutler \& M. L. Malik (Eds.), Rethinking the DSM: A psychological perspective (pp.17-65). Washington, DC: APA Books.

Jensen P. S., \& Hoagwood, K. (1997). The book of names: DSM-IV in context. Development and Psychopathology, 9, 231-249.

Krause, K-L, Bochner, S., \& Duchesne, S. (2003). Educational psychology for learning and teaching. Victoria, Australia: Thomson.

Luthar, S. S., \& Zelazo, L. B. (2003). Research on resilience: An integrative review. In S. S. Luthar (Ed.), Resilience and vulnerability: Adaptation in the context of childhood adversities (pp. 510-549). Cambridge, UK: Cambridge University Press.

Maddux, J. E. (2002). Stopping the "madness": Positive psychology and the deconstruction of the illness ideology and the DSM. In C. R. Synder \& S. J. Lopez (Eds.), Handbook of positive psychology (pp. 13-25). New York: Oxford University Press.

Masten, A. S. (2001). Ordinary magic: Resilience processes in development. American Psychologist, 56, 227-238.

Masten A. S., \& Powell, J. L. (2003). A resilience framework for research, policy, and practice. In S. S. Luthar (Ed.), Resilience and vulnerability: Adapatation in the context of childhood adversities (pp. 1-25). New York: Cambridge University Press.

Ministry of Social Development. (2002). New Zealand's Agenda for Children: Making life better for children. Wellington: Author.

Ministry of Youth Affairs. (2002). Youth Development Strategy Aotearoa: Action for child and youth development. Wellington: Author. 
Neilson, W. (2005). Disability: Attitudes, history, and discourses. In D. Fraser, R. Moltzen, \& K. Ryba (2005), Learners with special needs in Aotearoa New Zealand (3rd ed., pp. 9-21). Victoria, Australia: Thomson.

O’Brien, P., \& Ryba, K. (2005). Policies and systems in special education. In D. Fraser, R. Moltzen, \& K. Ryba (Eds.), Learners with special needs in Aotearoa New Zealand ( $3^{\text {rd }}$ ed., pp. 22-48). Southbank, Victoria: Thomson.

Pinto-Correia, C. (1997). The ovary of Eve: Egg and sperm and preformation. Chicago: University of Chicago Press.

Read, J., \& Masson, J. (2004). Genetics, eugenics and mass murder. In J. Read, L. R. Mosher, \& R. P. Bentall (Eds.), Models of madness: Psychological, social and biological approaches to schizophrenia (pp. 35-42). East Sussex, UK: Brunner.

Reid, J. B., Patterson, G. R., \& Synder, J. (Eds.). (2002). Antisocial behavior in children and adolescents: $A$ developmental analysis and model for intervention. Washington, DC: APA Books.

Sameroff, A. J. (1995). General systems theories and developmental psychopathology. In D. Cicchetti \& D. J. Cohen (Eds.), Developmental psychopathology, Volume 1: Theory and methods (pp. 659-695). New York: Wiley.

Sameroff, A. J. (2000). Developmental systems and psychopathology. Development and Psychopathology, 12, 297-312.

Santrock, J. W. (2006). Life-span development (10th ed.). Boston: McGraw-Hill.

Schaler, J. A. (Ed.). (2004). Szasz under fire: The psychiatric abolitionist faces his critics. Chicago: Open Court.

Seligman, M. E. P. (2002). Positive psychology, positive prevention, and positive therapy. In C. R. Synder \& S. J. Lopez (Eds.), Handbook of positive psychology (pp. 3-9). New York: Oxford University Press.

Singh, N. N. (2001). Personal reflections: Biological factors. In J. Kauffman, Characteristics of emotional and behavioral disorders of children and youth (7th ed., pp. 221-223). Upper Saddle River, NJ: Merrill Prentice-Hall.

Stanley, P. (2003). Risk and resilience: Part 1, Theory. Kairaranga. The Journal of New Zealand Resource Teachers of Learning and Behaviour, 4(1), 4-7.

Stanley, P., \& Stanley, L. (2005). Prevention through parent training: Making more of a difference. Kairaranga 6(1), 47-54.

Sullivan, M. (1991). From personal tragedy to social oppression: The medical model and social theories of disability. New Zealand Journal of Industrial Relations, 16, 255-272.

Szasz, T. (1974). Ideology and insanity. Essays on the psychiatric dehumanization of man. Harmondsworth, UK: Penguin. (Original work published 1970)
Taylor, A. J. W. (2002). In praise of an all-round psychologist: Sir Thomas Hunter. The Bulletin, 101, 26-35.

Thakker, J., \& Ward, T. (1998). Culture and classification: The cross-cultural application of the DSM-IV. Clinical Psychology Review, 18, 501-529.

Turnbull, A. P., Turbiville, V., \& Turnbull, H.R. (2000). Evolution of family-professional partnerships: Collective empowerment as the model for the early twenty-first century. In J. P. Shonkoff \& S. J. Meisels (Eds.), Handbook of early childhood intervention (2nd ed., pp. 630-650). Cambridge, UK: Cambridge University Press.

Van der Klift, E., \& Kunc, N. (1994). Beyond benevolence: Friendship and the politics of help. In J. S. Thousand, R. A. Villa, \& A. I. Nevin (Eds.), Creativity and collaborative learning: A practical guide to empowering students and teachers (pp. 391-401). Baltimore, MD: Paul Brookes.

Zigler, E., \& Hodapp, R. M. (1986). Understanding mental retardation. Cambridge, UK: Cambridge University Press.

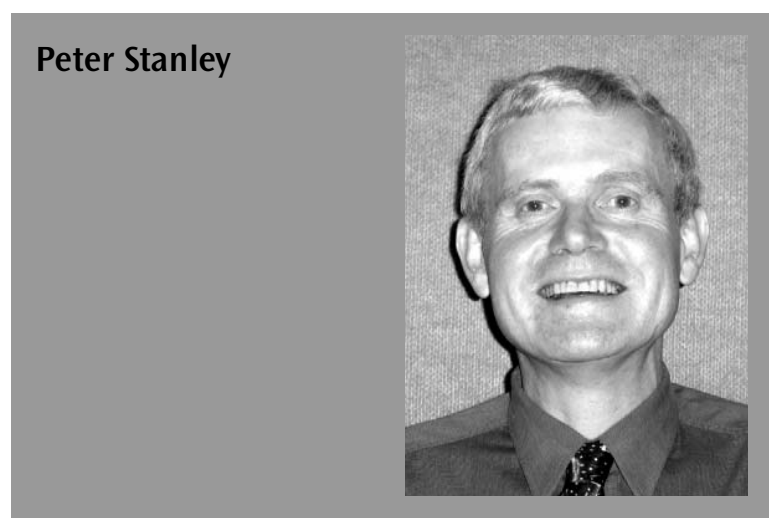

\section{AUTHOR PROFILE}

Peter Stanley is a senior lecturer in the Department of Human Development and Counselling at The University of Waikato in Tauranga. He is also a psychologist and he previously worked for Ministry of Education, Special Education.

\section{Email}

peter@waikato.ac.nz 